\title{
Economic and Environmental Benefit of Trees in an Urban Centre.
}

\author{
${ }^{1}$ J.T. Owolabi, Ph.D, ${ }^{2}$ Prof. W.O. Adebayo \\ ${ }^{1,2}$ Department Of Geography And Planning Science, Ekiti State University.
}

\section{Introduction}

Trees play important roles in maintaining a virile and sustainable environment. Trees provide the means of paying "carbon debt", this is done as it absorbed carbon IV oxide $\left(\mathrm{CO}_{2}\right)$ and gives out oxygen. When most of these trees are destroyed and used as fuel wood, planks for building etc we have more carbon IV oxide circulating in the air causing more havoc (Adebayo and Owolabi, 2004). Too much carbon IV oxide in the atmosphere causes more heat to be trapped within the atmosphere which contributes immensely to global warming and climate change (Adebayo, 1991, 1997, 1999; 2010; Ayoade, 2003).

Trees are the oldest and largest living things on the earth, and they are a good measure of the health and quality of our environment. Trees are the original multi-takers. Trees provide social, ecological and economic benefits. Their beauty inspires writers and artists while their leaves and roots clean the air we breathe and the water we drink among other things (Adebayo, 1997; Adebayo \& Owolabi, 2004).

Trees are indicators of a community's ecological health. When trees are large and healthy, the ecological systems - soil, air and water - that support them are also healthy. In turn, healthy trees provide valuable environmental benefits. The greater the tree cover and the less the impervious surface, the more ecosystem services are produced in terms of reducing storm water runoff, increasing air and water quality, storing and sequestering atmospheric carbon and reducing energy consumption due to direct shading of residential buildings (Adebayo \& Owolabi, 2004).

Urban vegetation is very important for people's living because it not only provides visual joy for people, but also influences directly or indirectly, urban environment through its physical characteristics (Zhang \& Feng, 2005). For example, it influences urban environmental conditions and energy fluxes by selective reflection and absorption of solar radiation and by modulation of evapo-transpiration (Small, 2001). Thus, a reliable measure to the distribution of urban vegetation is getting more significant. At present, several studies have pointed to urban green spaces as a resource in promoting public health and providing valuable ecosystem services to urban dwellers (Maas et al. 2006; Alvery, 2006; Jim and Chem, 2008; Rafiee et al. 2009; James et al. 2009).

Urban forestry is not a new concept, but it is one which appears to have growing potential. This is particularly true in developing countries where urbanization is increasing at a rapid rate and a demographic switch from a predominantly rural to a predominantly urban society is taking place. Although United Nations (1991) figures indicate that in 1990 only $37 \%$ of the total population of developing countries was urbanized, it is predicted that by the year 2025 the proportion will be $61 \%$. Already rapid and uncontrolled urbanization in many developing countries is having fundamental social and environmental consequences. The role of urban trees in ameliorating this situation might, at first thought, appear to be small. Yet, urban forestry may provide Third World town and city dwellers with significant environmental and material benefits.

\section{Data Collection}

\section{Research Method}

Data on economic and environmental benefit were obtained through administration of questionnaire, personal observation, survey and interview. The study area was divided into five zones for easy data collection and for comparison purposes. A total of 1,200 copies of questionnaires were administered in the study area. Due to aerial differentiation of the zones, 260 copies of questionnaires were administered in each of zones 1, 3, 4 and 5 while 160 copies of questionnaires were administered in zone 2. Systematic random sampling techniques were used in administering the questionnaire.

\section{Discussion Of Results}

There are a lot of reasons why individuals, corporate bodies or the public sector plant trees. But in table 1, we categorized the reasons into five. In zone $1,27.1 \%$ of the respondents planted trees to beautify their compound while $24.8 \%$ used it in the form of recreational activities where some sorts of indoor games such as 'Ayo Olopon', draft, ludo, etc. were played after the day's work. $44.1 \%$ of the respondents planted trees so that 
the fruits could be consumed as food while those that planted trees as sources of fuel wood and for economic reasons were just $1.6 \%$ and $2.4 \%$ respectively.

In zone $2,27.5 \%$ of the respondents planted trees for landscaping purposes while $32.5 \%$ planted it for recreational activities. Those that planted it in order to eat the fruits were $26.3 \%$ while $3.8 \%$ and $10.0 \%$ planted trees specifically for fuel wood and economic purposes respectively. In the remaining three zones, i.e. zones 3 , 4 and 5, the percentage distribution followed almost the same trend as landscaping has the highest percentage followed by recreational activities with food or fruits trailing them and economic activities while those who planted trees as a source of fuel wood had the least percentages. Generally, this shows that people have now understood the beautification power of trees and its recreational capabilities.

Table 1: Reasons for Tree Planting

\begin{tabular}{|c|c|c|c|c|c|c|c|c|c|c|c|c|}
\hline \multirow{3}{*}{ REASONS } & \multicolumn{12}{|c|}{ NO OF RESPONSE } \\
\hline & \multicolumn{2}{|c|}{ ZONE 1} & \multicolumn{2}{|c|}{ ZONE 2} & \multicolumn{2}{|c|}{ ZONE 3} & \multicolumn{2}{|c|}{ ZONE 4} & \multicolumn{2}{|c|}{ ZONE 5} & \multirow{2}{*}{$\begin{array}{l}\text { CEMULATIVE } \\
\text { TOTAL. }\end{array}$} & \multirow[b]{2}{*}{$0 \%$} \\
\hline & No & $\%$ & No & $\%$ & No & $\%$ & No & $\%$ & No & $\%$ & & \\
\hline Landucaping & 69 & 27.1 & 22 & 27.5 & 85 & 34.7 & 43 & 31.4 & 78 & 31.7 & 297 & 31.9 \\
\hline $\begin{array}{l}\text { Recreational } \\
\text { Ayo Lede and } \\
\text { Draft }\end{array}$ & 63 & 24.8 & 26 & 32.5 & 68 & 27.8 & 4 & 24.8 & 70 & 28.5 & 231 & 24.8 \\
\hline Food (Fruits) & 112 & 44.1 & 21 & 26.3 & 75 & 30.6 & 34 & 24.8 & 67 & 27.2 & 309 & 33.2 \\
\hline Fuel wood & 4 & 1.6 & 03 & 3.8 & 4 & 1.6 & 11 & 8.0 & 15 & 6.1 & 37 & 4,0 \\
\hline $\begin{array}{l}\text { Economic } \\
\text { Purposes }\end{array}$ & 6 & 2.4 & 08 & 10.0 & 12 & 4.9 & 15 & 1.9 & 16 & 6.5 & 57 & 6.1 \\
\hline Total & 254 & 100 & 80 & 100 & 245 & 100 & 137 & 100 & 246 & 100 & 931 & 100 \\
\hline
\end{tabular}

Source: Field Survey, 2012

There are a lot of advantages that could be derived from the planting of trees in a compound. For easy explanation and discussion, it was grouped under four sub-headings as shown in table 2. In Zone 1, 43.5\% of the respondents said they used the trees as a source of relaxation centre for the family, while in zone 2, it was $45.7 \%$ of the respondents. Zone 3 had 39.6\% which was the highest in the zone and zone 4 and 5 had $31.2 \%$ and $44.7 \%$ of the responses obtained. Some respondents used the trees as a means of moderating the temperature in their compounds. $46.5 \%$ and $29.6 \%$ in zones 1 and 2 respectively believed that the trees were to give sucour for the high temperature that was being experienced. Zone 3, 4 and 5 had $26.1 \%, 29.4 \%$ and $32.6 \%$ respectively also supported the view. 5\% of the respondents in zone 1 used the trees in their compound to boost the economy of the family by selling the fruit while $9.9 \%$ and $28.6 \%$ in Zones 2 and 3 were of the same opinion. $13.4 \%$ in Zone 4 and $21.9 \%$ in Zone 5 shared the same view. Very few respondents had the opinion of cutting down the branches of the trees for fuel wood. The percentages range between $0.8 \%$ in zone 5 and $6.2 \%$ in zone 2. Some of the respondents believed that trees could be planted for all of the aforementioned groups. For instance, $1 \%$ in zone 3 , and $21 \%$ in Zone 4 all said the trees were there for all of the above options. This corroborated the opinion of Afolabi (2006) that human life depends on other species for food, shelter, and breathable air, waste assimilation and other environmental life-support services. All these could be obtained from planting trees in and around our city environments.

Table 2: Advantages Of Tree(S) Planted In The Compound

\begin{tabular}{|c|c|c|c|c|c|c|c|c|c|c|c|c|}
\hline ADVANTAGES & \multicolumn{12}{|c|}{ NO OF RESPONSE } \\
\hline $\begin{array}{l}\text { Relaxation centre for the } \\
\text { family }\end{array}$ & 88 & 43.5 & 37 & 45.7 & 97 & 39.6 & 37 & 31.2 & 110 & 44.7 & 369 & 41.3 \\
\hline $\begin{array}{l}\text { Boosting the economy of the } \\
\text { family by selling the fruits }\end{array}$ & 10 & 5.0 & 08 & 9.9 & 70 & 28.6 & 16 & 13.4 & 54 & 21.9 & 158 & 17.7 \\
\hline $\begin{array}{l}\text { Branches cut down for } \\
\text { fuelwood }\end{array}$ & 8 & 4.0 & 05 & 6.2 & 12 & 4.9 & 6 & 5.0 & 2 & 0.8 & 33 & 3.7 \\
\hline Total & 202 & 100 & 81 & 100 & 245 & 100 & 119 & 100 & 246 & 100 & 893 & 100 \\
\hline
\end{tabular}

Source: Field Survey, 2012

Table 3 shows the different ways of harvesting and selling of the economic trees in the compounds. In all the zones of the study area, highest percentages of the respondents (zone 1, 92\%; zone 2, 82.2\%; zone 3, 65.8\%; zone 4, 39\%; and zone 5,72.4\%) preferred to harvest the fruits and consume them within the family and friends. They said they used it to supplement the sources of food for the family. A sizeable number of the respondents also harvested and sold the fruits in pieces to individuals. The percentage range between $1.8 \%$ in zone 1 and $26.1 \%$ in zone 3. Very few respondents harvested their fruits and sold in bulk to individual, as low as $0.9 \%$ in zone 1 . Zone 4 had an exception with approximately $34 \%$ of the respondents. Some of the respondents said it also served as a source of raw materials to industries as zones 1 to 5 had $5.3 \%, 1.3 \%, 1.9 \%, 4.9 \%$ and $3.3 \%$ respectively of their respondents harvesting their fruits and sold in bulk to industries and companies. In general, it could be observed that tree planting could be used to boost food production and also as a source of raw 
materials for industries. This assertion agreed with FAO (1999) where they suggested that tree planting could be used to boost food production and poverty reduction in the developing countries.

TABLE 3: Harvesting And Selling Of The Economic Trees In The Compound

\begin{tabular}{|c|c|c|c|c|c|c|c|c|c|c|c|c|}
\hline \multirow{2}{*}{ METHODS } & \multicolumn{12}{|c|}{ NO OF RESPONSE } \\
\hline & No & $\%$ & $\begin{array}{l}\mathbf{N} \\
\mathbf{O}\end{array}$ & $\%$ & No & $\%$ & $\begin{array}{l}\mathbf{N} \\
\mathbf{O}\end{array}$ & $\%$ & $\begin{array}{l}\mathbf{N} \\
\mathbf{O}\end{array}$ & $\%$ & $\begin{array}{c}\text { CUMULATI } \\
\text { VE } \\
\text { TOTAL }\end{array}$ & $\%$ \\
\hline $\begin{array}{l}\text { Harvested \& sold in } \\
\text { pieces to individual }\end{array}$ & 2 & 1.8 & 18 & 11.9 & 42 & 26.1 & 18 & 22 & 36 & 19.9 & 116 & 16.9 \\
\hline $\begin{array}{l}\text { Harvest \& sold in bulk to } \\
\text { individual }\end{array}$ & 1 & 0.9 & 6 & 4 & 10 & 6.2 & 28 & 34.1 & 8 & 4.4 & 53 & 7.7 \\
\hline $\begin{array}{l}\text { Harvested \& eold in bulk } \\
\text { to Industry \& Comp. }\end{array}$ & 6 & 5.3 & 2 & 1.3 & 3 & 1.9 & 4 & 4.9 & 6 & 3.3 & 21 & 3.1 \\
\hline Total & 111 & 100 & $\begin{array}{c}15 \\
1\end{array}$ & 100 & 161 & 100 & 82 & 100 & $\begin{array}{c}18 \\
1\end{array}$ & 100 & 686 & 100 \\
\hline
\end{tabular}

Source: Field Survey, 2012

Due to the high undulating nature of the topography of the town with a lot of hills, both vegetated and non-vegetated, there were a lot of steeply sloping, erosion prone land on urban fringe of the hills . On the slope of each of the hills, there were some that had trees and shrubs e.g. Christ School hills, which in turn could control both the erosional activities in the area and moderation of urban heat . On the other hand, there were some non-vegetated hills that were nearly bare, that is, without vegetative cover, and when rain falls, they aid the fast movement of the water down the hill, thereby causing erosion, flooding and even rock slide e.g. Idolofin hill at Odo-Ado and Olokemeji area. The vegetated hills aid a good urban ecosystem by providing habitat for species of many kinds, protect the soils and helps in paying "Carbon debt". At the base of the non-vegetated hills, people should be encouraged to plant trees, grasses and scrubs as these areas have great potentials for urban forestry which could be managed for the reduction of urban poverty.

\section{Conclusion}

A city wide master plan and landscape of Ado-Ekiti is needed to spell out long-term objectives and implementation approaches to overhaul the urban environmental quality. There is the need for mass mobilization of individuals, schools, companies, voluntary organizations, parastatals, traditional rulers including street or quarter heads, to be involved in mass tree-planting exercises on a regular basis, to halt disasters resulting from deforestation. In this respect the state government should enact laws that make it mandatory for every building to plant at least a tree in his/her compound.

\section{Reference}

[1] Adebayo W. O. (1991) "Temperature Trends in Nigeria" Unpublished M.Sc. Thesis, Department of Geography University of Ibadan.

[2] Adebayo, W. O. (1997) "Heat Island and Oasis Effect of Vegetative Canopies: A Micro-meteorological Investigation". International Journal of Urban and Regional Affairs, Vol. 1. No 1, pg 35-39.

[3] Adebayo W. O. (1999) "The Spatial - Temporal Dynamics of Temperature and Rainfall Fluctuations in Nigeria". Unpublished Ph.D Thesis, Department of Geography University of Ibadan.

[4] Adebayo, W. O. and Owolabi J. T. (2004) "Micro Climate Relationships of Open Space and Vegetative Canopy in an urban Environment" Journal of the Social Sciences, Vol 3, No 1 Pp 41-47.

[5] Adebayo, W. O. (2010), The Human Environment: Something to Everyone, University of Ado-Ekiti, The Twenty Nineth Inaugural Lecture. $75 \mathrm{pg}$

[6] Alvery, A. A. (2006). Promoting and preserving biodiversity in the urban forest. Urban Forestry and urban Greening 5 (4): 195201.

[7] Ayoade, J. O. (2003) Climate Change: A Synopsis of its Nature, Causes, Effects and Management, Ibadan, Vintage Publishers Ltd.

[8] James, P. Tzoulas, K; Adams, M. D.; Barber, A.; Box, T.; Brauste, J.; Elmqvist, T.; Frith, M.; Gordom, C.; Greeming, K. L.; Handley, J.; Haworth, S.; Kazmierrzak, A. E.; Johnston, M.; Korpela, K.; Moretti, M.; Niemela, J.; Pauleit, S.; Roe, M. H.; Sadler, J. P.; and Ward, Thompson C. (2009). Towards an Integrated Understanding of Green Space in the European Built Environment. Urban Forestry and Urban Greening; 8 (2); 65-75.

[9] Jim, C. Y. and Chem W. Y. (2008): Pattern and divergence of tree communities in Taipei's main urban green spaces. Landscape and Urban Planning: 84; 312-323.

[10] Maas, J.; Verheij, R. A; Groenenegen, P. P; de Vriees, S., Spreeuwenberg, P. (2006); Green space, urbanity, and health; how strong is the relation? Journal of Epidemiology and Community Health: 60 587-592.

[11] Rafiee, R., Mahiny, A. S. and Khorasani, N. (2009). Assessment of Changes in Urban Green Spaces of Mashad City Using Satellite Data, International Journal of Applied Earth Observation and Geoinformation; 11:431-438.

[12] Small, C. (2001) "Estimation of Urban Vegetation Abundance BySpectral mixture Analysis" International Journal of Remote Sensing, Vol. 22, pp 1305-1334.

[13] United Nations, (1991) "World Urbanization Prospects: 1990

[14] Estimates and Projections of Urban and Rural Population and Urban Agglomerations” Department of International Economic and Social Affairs, New York, USA.

[15] Zhang, X. and Feng, Zuezhi (2005) "Detecting Urban Vegetation from Ikonos Data using An Object Oriented Apoproach". A sponsored Research by Jiangsu Province Natural Foundation, China. 